\title{
Study of the 5E Instructional Model to Improve the Instructional Design Process of Novice Teachers
}

\author{
Jiuhua $\mathrm{Hu}^{1, *}$, Chong $\mathrm{Gao}^{2}$, Yang Liu ${ }^{1}$ \\ ${ }^{1}$ College of Chemistry, Beijing Normal University, China \\ ${ }^{2}$ The High School Affiliated to Minzu University of China, China
}

Copyright $\mathrm{O} 2017$ by authors, all rights reserved. Authors agree that this article remains permanently open access under the terms of the Creative Commons Attribution License 4.0 International License

\begin{abstract}
This study investigated the effects of $5 \mathrm{E}$ instructional model on the teaching processes of novice teachers. First, we conducted a teaching design training project based on the $5 \mathrm{E}$ model for 40 novice teachers, and compared pre-texts of the teachers' teaching process from before the training with post-texts obtained immediately following the training to determine whether the model can promote the teaching design process of novice teachers. In order to explore how the 5E model influenced the novice teachers' teaching processes, we chose three teachers for an additional three stages of training, then compared the texts resulting from the different stages and interviewed each teacher. Finally, we found that the $5 \mathrm{E}$ model had a significant effect on the improvement and further development of the teaching processes among the novice teachers. The model influenced the teachers' teaching process through each of the sub-phases, and different sub-phases resulted in different improvements. Each novice teacher also showed different improvements, with the specific improvements also being affected by teachers' personal beliefs.
\end{abstract}

Keywords 5E Instructional Model, Novice Teachers, Teaching Process, Curriculum Design, Improvement

\section{Introduction}

The 5E instructional model has been widely applied in the education of teaching practices since it was proposed. Its five phases (Es) are engagement, exploration, explanation, elaboration, and evaluation. The $5 \mathrm{E}$ instructional model has the potential to change traditional teaching and give students opportunities to explore. [1] It can also help teachers become better able to make use of students' prior knowledge and help students construct new knowledge. [2] The study of the 5E instructional model covers multiple aspects of educational practice. Studies have shown that compared with traditional teaching models, the $5 \mathrm{E}$ model results in greater benefits in terms of stronger student interest in learning and greater ability for scientific inquiry. [3] Thus, the 5E model has been found to have a positive impact on student academic achievement and learning ability. ${ }^{[4-6]}$ In recent years, some studies have tried to investigate the effect of the $5 \mathrm{E}$ model on prospective teachers' conceptual understanding of specific knowledge contexts, and the results showed that the $5 \mathrm{E}$ model could promote changes in the prospective teachers' conceptual thinking.[7-8] However, it remains unclear whether the 5E model could help novice teachers by improving their teaching process, which is a significant factor in their professional development.

Teachers' professional development plays an important role in the field of educational research, and such studies are often accompanied by teacher training. [9] At present, teacher training and teaching improvement mainly focus on the ways in which improvement can be achieved. [10] For example, some studies suggest that cooperative teaching is an effective way to promote improved teaching by novice teachers. [11-12] Instruction based on the 5E method may be able to improve the teaching processes of novice teachers because it incorporates clear stages. Thus, it is necessary to determine whether the teaching processes of novice teachers can actually be improved following training in the $5 \mathrm{E}$ model's instructional methods.

The 5E model has clear applications and implications for teaching and curriculum design, so it should be especially helpful for novice teachers whose personal teaching styles are still being formed. This study therefore aimed to investigate the effect of the $5 \mathrm{E}$ model on the teaching processes of novice teachers. We conducted our study with a group of novice teachers to determine whether the $5 \mathrm{E}$ model can affect the teaching processes of the teachers. We also performed case studies consisting of three stages to more deeply examine how the model influences the teachers' teaching processes.

\section{Methodology and Methods}

\subsection{Participants}

The group of teachers who participated in our study 
consisted of 40 novice chemistry teachers working in different cities in China, including five from Inner Mongolia, four from Hubei, and four from Henan. The 40 teachers from different levels of school in China, who volunteered to participate in the summer training course.

The case studies were conducted with three of the teachers: MXY, XBB, and ZRL.

We selected three voluntary and representative teachers from 40 novice chemistry teachers. MXY showed excellent performance in her teaching process and course design work during her time as a master's student. She also exhibited good modern teaching concepts and teaching skills as a female teacher in a good school during her 1 year of work following graduation. XBB is a male teacher who has worked for 2 years in an excellent school. He noted that his curriculum does not efficiently capture his students' attention, resulting in low engagement. He also lamented that he cannot design effective exploration tasks, and that the students exhibit little attention during the evaluation parts of his course. He therefore looked forward to improving his ability to design his own teaching process and curriculums. ZRL is a female teacher who has worked for 2 years in an ordinary school. She also wanted to improve her ability to design her own teaching process in her curriculum, in which the current primary teaching method is discussion.

While these three teachers are similar with respect to being relatively novice, they are also very different with respect to their educational backgrounds, years of working, and current working conditions. These similarities and differences will help ensure that the $5 \mathrm{E}$ instructional model can realize an effective and comprehensive result with respect to the improvement of the teachers' teaching processes.

\subsection{Procedure and Instruments}

To explore the influence of the $5 \mathrm{E}$ model on the design of one's personal teaching process, 40 novice teachers were selected for the study. Through a comparison of the teaching processes from before and after the introduction of, and instruction in, the 5E model, we investigated whether the model could promote improvement in the development of the teaching process among the teachers. Following the initial comparisons with the group of 40 teachers, we subsequently selected three teachers to more closely examine their individual teaching processes based on the $5 \mathrm{E}$ model across three stages. The full study design is shown in Figure 1.

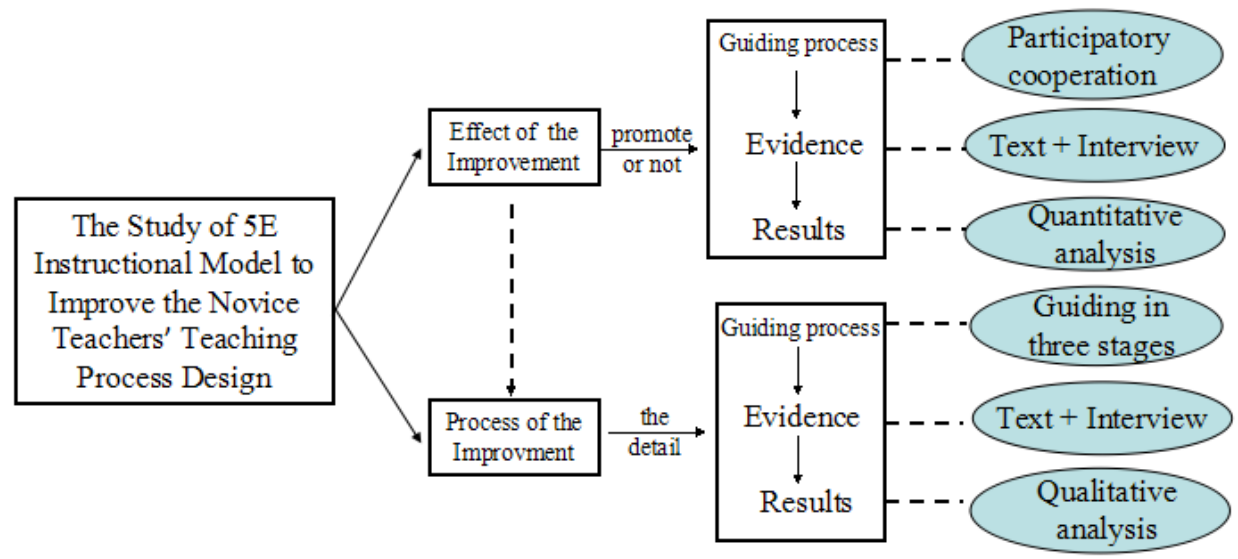

Figure 1. Illustration of study design of investigating the effects of $5 \mathrm{E}$ model instruction on the teaching processes of novice teachers.

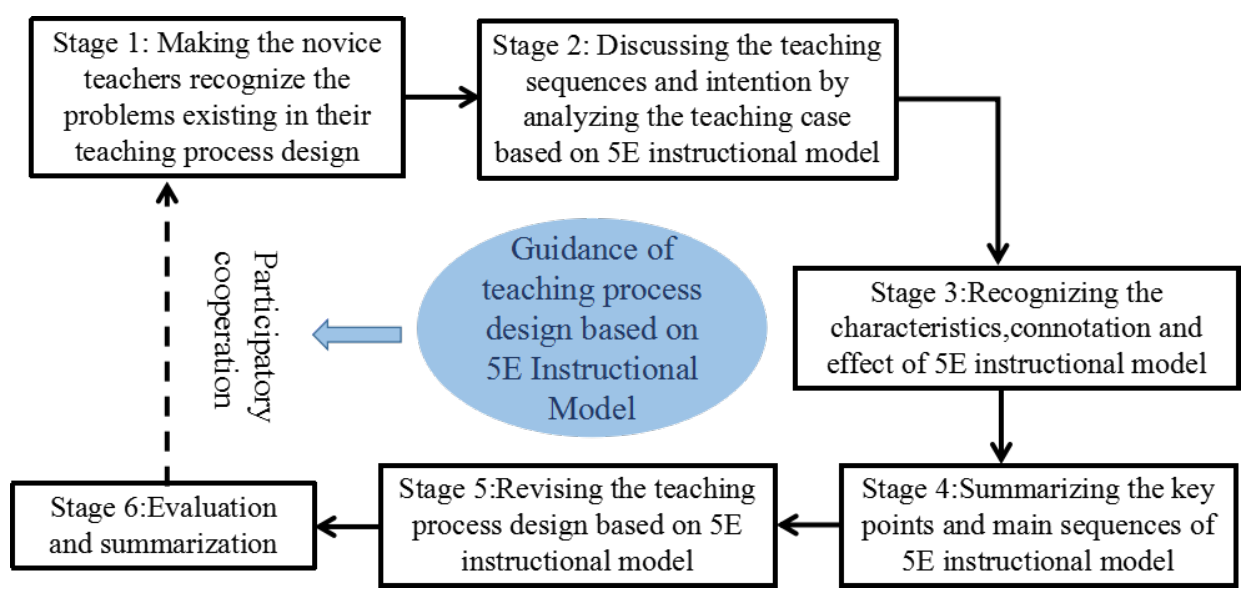

Figure 2. Flow of group instruction activities for teaching processes based on the $5 \mathrm{E}$ instructional model 
A series of instructional activities were performed with respect to teaching processes based on the $5 \mathrm{E}$ instructional model for the novice teachers, and these activities were observed and measured through participatory cooperation. The researcher and the teachers worked together for all of the activities. The activities began in July, 2014, and lasted for a total of 4 months. Figure 2 shows the order of these activities.

Details of each of these instructional stages are provided below.

Stage 1

The questionnaire data include: (1) the percentage of responses for each choice on several representative questions; (2) feedback regarding present teaching processes among the novice teachers; (3) confirmation questions regarding the teachers' present methods of developing their teaching processes; (4) prompts for reflection and problem identification regarding what is needed in the design of teaching processes.

Stage 2

In this stage, we instructed the novice teachers to analyze a $5 \mathrm{E}$ case of "Chemical Energy into Electrical Energy" as part of their curriculum design, including the five elements of engagement, exploration, explanation, elaboration, and evaluation. This is a typical $5 \mathrm{E}$ instructional model, in which the teaching activity, student activity, and design purpose are all clearly contained within each element. The analysis first proceeded by inquiring how the teachers felt about the instructional method, using questions including "Do you think it is a good way to design teaching processes?," "Which do you prefer?," and "What can we learn from this example of instructional design?" Next, to allow every participant to better understand the framework and priorities behind the $5 \mathrm{E}$ instructional method, further analyses were undertaken along with the asking of additional questions, such as, "How many elements or phases were contained in this example of instructional design?" and "What was the intention behind each element or phase?" Finally, the overall main purposes and design intentions were discussed with respect to the $5 \mathrm{E}$ model.

Stage 3

Under the researcher's instruction, the novice teachers answered questions and reported about problems based on the above discussion, allowing each teacher to gain a good understanding of the issues. The objectives and tasks of each phase of the model are shown below in Table 1 .

\section{Stage 4}

After gaining an understanding of the model, the novice teachers were instructed to analyze the instructional design of a second case, "Combustion and Extinguishing." The teachers extracted the operation points and phases of the case based on the model, then these points were subsequently discussed following the exercise. The researcher then added some additional explanations and conclusions related to the instructional design points based on the model.

\section{Stage 5}

The novice teachers were divided into 20 pairs, and each pair was asked to develop improvement suggestions based on the model. Then, two or three groups were selected to present their modified instructional designs to the rest of the group.

\section{Stage 6}

In addition to evaluating and summarizing instructional design based on the model, this study also introduced suggestions for improvement of the model itself. These efforts were expected to result in increased understanding and further applications of the model for instructional design among the novice teachers.

The three instructional periods were all between September and December, 2014, and each period lasted for 1 month. In the first period of instruction, the researcher provided a general introduction to the model to the novice teachers, then discussed the details, goals, and advantages of the model using appropriate case studies.

In the second period of instruction, the researcher instructed the novice teachers to design their own instructional process based on the model data (i.e., establishment model) after the novice teachers had become familiar with the model. The researcher then collected feedback from the novice teachers.

Table 1. Intentions of each phase of the $5 \mathrm{E}$ instructional model

\begin{tabular}{|c|c|c|}
\hline \multicolumn{2}{|c|}{ Phase } & Teaching objectives and tasks \\
\hline \multicolumn{2}{|c|}{ Engagement } & Accessing the learners' prior knowledge, promoting curiosity and elicit prior knowledge, causing cognitive conflict \\
and problems to explore.
\end{tabular}


In the third period, the researcher encouraged the novice teachers to employ the model to the design of their own instructional processes based on their current understanding of the $5 \mathrm{E}$ model, then subsequently provide feedback to the researcher.

\subsection{Data Collection and Analysis}

The researcher collected the 40 participants' texts related to their instructional design process at different stages based on the model. The texts were divided into three groups: before instruction, immediately after instruction, and 3 months after instruction. The researcher then analyzed each text comprehensively to extract the relevant content and data points. An evaluation of the instructional design at each phase in the model was made, with a possible total score of 100 for the entire instructional design process. There were four evaluation points for each phase, and each evaluation point was given a score between 1 and 5. The evaluation points for each instructional design phase are shown in Table 2.

The analyses of the data were performed by collating the 40 novice teachers' scores for the different phases for the three kinds of instructional design, to determine whether there was any improvement in the teachers' instructional design process based on the model. As for the case study data, the instructional design texts and teacher interview data were collected at different periods, and any improvements, further development, as well as differences between the teachers with respect to their instructional processes were explored by analyzing the data based on the model.

\section{Results and Discussion}

\subsection{Result and Discussion of Improvements in Instructional Process Design Based on the 5E Instructional Model}

Three months following the conclusion of the study, the researchers collected the instructional process design texts from the 40 novice teachers. The collected data were analyzed by scoring each phase according to a standard scoring procedure, which included the three periods of instruction that resulted in the texts from before the instruction, immediately after the instruction, and 3 months after the instruction. A significance analysis was performed according to both the overall scores and each phase's score. The significance analysis results for the overall instructional design process are shown in Table 3.

Table 2. Evaluation model for instructional design process of the novel teachers

\begin{tabular}{|c|c|}
\hline Phase & Requirements and key points of instructional process design \\
\hline \multirow{4}{*}{ Engagement } & Creating a scene to promote student curiosity \\
\hline & Eliciting students' prior knowledge \\
\hline & Creating students' cognitive conflicts \\
\hline & Organizing students' thinking and finding problems to explore \\
\hline \multirow{4}{*}{ Exploration } & Providing students with a common base of activities \\
\hline & Initiating of activity by teacher and allowing students time and opportunities to investigate \\
\hline & Probing questions when necessary, and guiding students indirectly \\
\hline & Creating a sense of "wanting to learn" and giving students time to raise questions when exploring \\
\hline \multirow{4}{*}{ Explanation } & Encouraging students to discuss and analyze the process themselves \\
\hline & Asking students to provide explanations about new concepts \\
\hline & Introducing (by the teacher) of scientific or technological explanations in a direct, explicit, and formal manner \\
\hline & Using student experiences as the basis of explaining new knowledge \\
\hline \multirow{4}{*}{ Elaboration } & Creating new and unfamiliar problem situations for student applications \\
\hline & Encouraging students to participate in discussions for strengthening the understanding of new knowledge \\
\hline & Guiding students to analyze problems from multiple angles and expanding new knowledge \\
\hline & Guiding students to summarize the corresponding knowledge, processes, and methods \\
\hline \multirow{4}{*}{ Evaluation } & Allowing the students to reflect and evaluate their own knowledge and skills when learning \\
\hline & Observing and evaluating the students' new knowledge and skills \\
\hline & Assessing students' knowledge and skills and giving them suggestions \\
\hline & Evaluating the students' gradual development of understanding in every teaching phase \\
\hline
\end{tabular}


Table 3. Results of analysis of novice teachers' instructional process depending on the time period of data collection

\begin{tabular}{|c|c|c|c|c|c|c|c|c|}
\hline & \multicolumn{5}{|c|}{ Paired Difference } & \multirow{3}{*}{$\mathrm{t}$} & \multirow{3}{*}{$\mathrm{df}$} & \multirow{3}{*}{$\begin{array}{c}\text { Sig. } \\
(2 \text {-tailed })\end{array}$} \\
\hline & \multirow{2}{*}{ Mean } & \multirow{2}{*}{$\begin{array}{c}\text { Std. } \\
\text { Deviation }\end{array}$} & \multirow{2}{*}{$\begin{array}{l}\text { Std. } \\
\text { Error } \\
\text { Mean }\end{array}$} & \multicolumn{2}{|c|}{$\begin{array}{c}95 \% \text { Confidence Interval of } \\
\text { the Difference }\end{array}$} & & & \\
\hline & & & & Lower & Uper & & & \\
\hline $\begin{array}{l}\text { Pairl: before the instruction --- } \\
\text { immediately after the instruction }\end{array}$ & -32.67500 & 4.95305 & .78315 & -34.25906 & -31.09094 & -41.723 & 39 & .000 \\
\hline $\begin{array}{l}\text { Pair2: before the instruction ---3 } \\
\text { months after the instruction }\end{array}$ & -31.50000 & 4.06360 & .64251 & -32.79960 & -30.20040 & -49.026 & 39 & .000 \\
\hline $\begin{array}{l}\text { Pair3: immediately after the } \\
\text { instruction ---3 months after the } \\
\text { instruction }\end{array}$ & 1.17500 & 4.31983 & .68302 & -.20655 & 2.55655 & 1.720 & 39 & .093 \\
\hline
\end{tabular}

Table 4. Teachers' instructional design process improvements in engagement phase

\begin{tabular}{|c|c|c|}
\hline Category of instructional design & Pre-Guidance & Post-Guidance \\
\hline Key Points of Engagement & $85.0 \%$ & $97.5 \%$ \\
\hline Creating a situation to promote student curiosity & $20.0 \%$ & $87.5 \%$ \\
\hline Eliciting students' prior knowledge & $10.0 \%$ & $70.0 \%$ \\
\hline Evoking students' cognitive conflict & $52.5 \%$ & $95.5 \%$ \\
\hline
\end{tabular}

Table 5. Teachers' instructional design process improvements in exploration phase

\begin{tabular}{|c|c|c|}
\hline Category of instructional design & Pre-Guidance & Post-Guidance \\
\hline Providing students with a common base of activities & $31.8 \%$ & $89.4 \%$ \\
\hline Initiating the activity and allowing the students time and opportunities to investigate & $36.4 \%$ & $87.9 \%$ \\
\hline Probing questions when necessary and guiding students indirectly & $7.6 \%$ & $68.2 \%$ \\
\hline $\begin{array}{c}\text { Creating a sense of "wanting to learn" and giving students time to raise questions } \\
\text { when exploring }\end{array}$ & $4.5 \%$ & $62.1 \%$ \\
\hline
\end{tabular}

Table 3 shows the data for the comparison of the overall teaching process design data between the before and after periods of instruction of the model for the 40 teachers. The level of significance was $0.000<0.05$, indicating a significant difference. These results demonstrate that the model both impacted and improved the instructional design for the novice teachers. As for the prior text and 3-month delayed text data, the level of significance was $0.000<0.05$, a significant difference, indicating that the model can produce sustained influences and improvements in the instructional design process. However, no significant difference was found between the text from immediately after the instruction and the 3-month delayed text data (i.e., $0.093>0.05$ ). This result indicates that the model can produce a stable influence on the instructional design process for novice teachers. Similar results were also found among the statistics for the individual stages, and taken together as a whole these results indicate that the model can produce significant and stable improvements for novice teachers in their instructional design processes.

Similar results were also found for each phase of the model, in which clear improvements were observed by a comparison with the prior and subsequent text data for the teachers.

The improvement results for the engagement phase are listed in Table 4. In the original (pre-instruction) instructional processes of the teachers, 34 of the 40 teachers were able to offer more novel and richer materials to attract their students' attention by creating questions for engagement, but only eight of the teachers could successfully identify their students' original thinking in the stage of engagement. Moreover, although 21 of the teachers could propose problems for exploration in the engagement phase, only four of them could effectively trigger their students' cognition conflicts, while problems without any student cognition conflicts were all proposed under the teachers' instruction. Conversely, the instructional design process was found to have improved under the model for the 40 teachers, in which there were 39 cases of the teacher designs triggering their students' attention. At the same time, 35 designs were found to motivate the students to expose their original thoughts, while 28 designs were able to trigger the students' cognitions regarding conflicts. The percentage of the teachers who were able to accomplish this task successfully increased from $20 \%$ to $87.5 \%$.

As for the next phase of the model, exploration, the improvement shown in this study is shown in Table 5. There were 23 teaching process design texts that were found to have improved. For example, the teachers could provide the backgrounds, study materials, and appliances for exploration for their students, and they could also encourage their students to explore and discuss these topics without 
any further teacher instruction.

As for the next phase of the 5E model, explanation, the observed improvement is shown in Table 6. In the pre-guidance period, the majority of the teachers' efforts were in imparting new knowledge on the students, while following the guidance, there were 36 novice teachers who could successfully instruct the students to discuss and analyze the exploration problems based on the model first, before directly imparting new knowledge on the students.

As for the next phase of the $5 \mathrm{E}$ model, elaboration, the results of the comparison between the pre-guidance and post-guidance, including studying and training based on the $5 \mathrm{E}$ teaching design model, are shown in Table 7 . In this phase, 35 novice teachers tried to build new and unfamiliar question scenarios for their students to learn new knowledge, which showed an improvement compared with the pre-guidance teaching designs.

As for the evaluation phase of the $5 \mathrm{E}$ model, the comparison of the 40 novice teachers' results between pre-guidance and following studying and training based on the model are shown in Table 8 . In the pre-guidance instructional design process, almost no teacher tried to evaluate their course during their classroom teaching. However, 22 of the teachers attempted to evaluate their students' levels of comprehension in every phase following instruction based on the model.

Table 6. Teachers' instructional design process improvements in explanation phase

\begin{tabular}{|c|c|c|}
\hline Key Points of Explanation & Pre-Guidance & Post-Guidance \\
\hline Encouraging students to discuss and analyze the process themselves & $22.7 \%$ & $90.0 \%$ \\
\hline Asking students to provide explanations about new concepts & $21.2 \%$ & $68.2 \%$ \\
\hline $\begin{array}{c}\text { Introduction (by the teacher) of scientific or technological explanations in a direct, } \\
\text { explicit, and formal manner }\end{array}$ & $18.2 \%$ & $69.7 \%$ \\
\hline Using the student experience as the basis of explaining new knowledge & $15.2 \%$ & $77.3 \%$ \\
\hline
\end{tabular}

Table 7. Teachers' instructional design improvements in elaboration phase

\begin{tabular}{|c|c|c|}
\hline Category of instructional design & Pre-Guidance & Post-Guidance \\
\hline Creating new and unfamiliar problem scenarios for student applications & $34.8 \%$ & $87.5 \%$ \\
\hline $\begin{array}{c}\text { Encouraging students to participate in discussions for strengthening their } \\
\text { understanding of new knowledge }\end{array}$ & $27.3 \%$ & $80.3 \%$ \\
\hline $\begin{array}{l}\text { Guiding students to analyze problems from multiple angles and expanding new } \\
\text { knowledge }\end{array}$ & $15.2 \%$ & $74.2 \%$ \\
\hline $\begin{array}{c}\text { Guiding students to summarize the corresponding knowledge, processes, and } \\
\text { methods }\end{array}$ & $34.8 \%$ & $72.7 \%$ \\
\hline
\end{tabular}

Table 8. Teachers' instructional design improvements in evaluation phase

\begin{tabular}{|c|c|c|}
\hline Category of instructional design & Pre-Guidance & Post-Guidance \\
\hline $\begin{array}{c}\text { Kllow Points of Evaluation students to reflect and evaluate their own knowledge and skills when } \\
\text { learning }\end{array}$ & $6.1 \%$ & $68.2 \%$ \\
\hline Observing and evaluating the students' new knowledge and new skills & $10.6 \%$ & $78.8 \%$ \\
\hline Assessing students' knowledge and skills and providing suggestions & $6.1 \%$ & $68.2 \%$ \\
\hline $\begin{array}{c}\text { Evaluating the students' gradual development of understanding in every teaching } \\
\text { phase }\end{array}$ & $0.0 \%$ & $55.0 \%$ \\
\hline
\end{tabular}


The above improvement data demonstrate that the model could promote significant and stable improvements in the design of instructional processes among the novice teachers. According to the interviews with the teachers, the main reason for this observed improvement was that the model can provide an ideal template for the design of instructional processes, which can offer rules for novice teachers based on the model. Moreover, the model can improve the novice teachers' awareness levels with respect to the many aspects of instructional design; for example, one teacher noted: "Only through these specific phases can students concretely frame the knowledge they have gained and actively form a specific problem to be solved under the instruction, in which the teachers can use their procedural knowledge throughout the process of instructional design." Meanwhile, the model also showed the novice teachers how to better improve their own instructional design processes; for example, one teacher noted: "There were no longer any design elements in my Engagement phase, but rather more instruction under my guidance to allow the students to identify and work with their own, independent thinking. The scenarios used for instruction must be related to real life and also help the students to find new knowledge, which can trigger conflicts in cognition within the students and thereby ignite their interest." According to the novice teacher interview data, the model provided an effective reference and template for the teachers in their own instructional design processes, and significant improvements were obtained with respect to their design processes based on the model.

\subsection{Results and Discussion of the Detailed Improvements Observed in Instructional Design Based on the 5E Model}

To explore the reasons why the instructional design processes improved for the novice teachers based on the model, three of the teachers were selected to further examine 1) what kind of changes occurred over time in their instructional design processes, 2) whether the observed improvements would be the same across different individuals, and 3) what kind of factors will affect the observed improvement. The study was divided into three periods to conduct this detailed analysis, and each period of analysis was given a score evaluation based on different criteria.

\subsubsection{Changes in the Instructional Design Processes of Three Novice Teachers}

According to the current analysis of different teachers' changes and improvement, all three teachers were observed to achieve improvement in their instructional design processes.

Before receiving guidance on the model, MXY had not considered the role of engagement design, and thus his efforts at curriculum engagement were ineffective. However, in the first period, following instruction in the $5 \mathrm{E}$ model,
MXY's problem scenarios triggered the students' attention and allowed them to explore their original cognitions; however, MXY was still unable to successfully initiate the students' cognition conflicts and thus could not explore the problem effectively. By the third period, however, MXY was able to trigger the students' attention and explore their original cognitions using her own problem scenario designs, which were also able to trigger the students' own conflict cognitions and proposals for the exploration of problems. After becoming familiar with the model, MXY was able to provide effective materials for exploration at the first period of exploration. As for the explanation phase, her instructional design process showed improvement at every period, which developed from the original (pre-guidance) "teacher's explanation" to ones in which the "students construct the explanations themselves with the teacher's supplementary information" in the third period. As for the elaboration phase, the main issue was that the design of problem scenarios for the application of new knowledge was not really a familiar process in the first two periods; nonetheless, the instructional design process was improved significantly by the third period. As for evaluation, while the teachers were unable to observe and evaluate the students to learn new knowledge and skills in the first two periods, significant improvements were achieved in the third period, in which the teachers became able to evaluate their students' study processes.

Before receiving instruction based on the model, teacher XBB had a good understanding of the model; nonetheless, XBB achieved a big breakthrough in his instructional design process during the first period. $\mathrm{XBB}$ was able to design a problem scenario well enough to trigger the students' conflict cognitions in the engagement phase of the first period. Even though there was no further significant developments in the second period, XBB explored the students' original cognitions effectively and produced exploration problems naturally in the third period, which achieved the highest scores. In the exploration phase, XBB developed a design for his students' self-exploration activity in the first period, and further improved the design of the exploration problem. In the explanation phase, XBB maintained the same development viewpoint as in the first two periods, that is, that teachers should be able to help their students to construct self-knowledge frameworks before passing on their new knowledge. However, XBB was able to perfect his "students' explanation." The most difficult phase for XBB was elaboration, in which XBB did worse in instructional design compared with the other phases. In this phase, the difficult aspect was the design of unfamiliar problem scenarios, despite the design being after instruction in the model. In the evaluation phase, XBB understood the model well and paid attention to the students' self-evaluations in the first two periods. In addition, XBB was even able to develop teacher evaluations of the students' study processes in the third period. 
Table 9. MXY's specific situation of instructional design across the three stages

\begin{tabular}{|c|c|c|c|c|c|c|}
\hline \multirow{2}{*}{ Stage } & \multicolumn{5}{|c|}{ Teaching process design $(20 * 5)$} & \multirow{2}{*}{$\begin{array}{l}\text { Identification of } \\
\text { the } 5 \mathrm{E}\end{array}$} \\
\hline & Engagement & Exploration & Explanation & Elaboration & Evaluation & \\
\hline \multirow[b]{2}{*}{ First } & 10 & 15 & 13 & 10 & 15 & \multirow[b]{2}{*}{$\begin{array}{l}\text { Agreed basically, } \\
\text { inspired by } \\
\text { exploration and } \\
\text { evaluation } \\
\text { especially. }\end{array}$} \\
\hline & $\begin{array}{l}\text { Causing students' } \\
\text { cognitive conflict } \\
\text { without eliciting } \\
\text { students' prior } \\
\text { knowledge. } \\
\end{array}$ & $\begin{array}{l}\text { Providing students } \\
\text { with a common } \\
\text { base of activities, } \\
\text { but didn't carry out } \\
\text { probing questions. }\end{array}$ & $\begin{array}{l}\text { Grave students the } \\
\text { chance to express, } \\
\text { but the new } \\
\text { knowledge was } \\
\text { told by teacher. }\end{array}$ & $\begin{array}{l}\text { The new } \\
\text { knowledge was to } \\
\text { applied in the } \\
\text { common exercise. }\end{array}$ & $\begin{array}{c}\text { Students evaluate } \\
\text { themselves, but } \\
\text { lack of teacher's } \\
\text { evaluation. }\end{array}$ & \\
\hline \multirow[b]{2}{*}{ Second } & 15 & 15 & 18 & 10 & 15 & \multirow[b]{2}{*}{$\begin{array}{l}\text { Agreed the link } \\
\text { of explanation } \\
\text { especially. }\end{array}$} \\
\hline & $\begin{array}{l}\text { Created a question } \\
\text { situation and caused } \\
\text { students attention, } \\
\text { but failed to come up } \\
\text { with a problem. }\end{array}$ & $\begin{array}{l}\text { Providing students } \\
\text { with a common } \\
\text { base of activities, } \\
\text { but still lack of } \\
\text { probing questions. }\end{array}$ & $\begin{array}{c}\text { Students } \\
\text { constructed new } \\
\text { knowledge } \\
\text { themselves. }\end{array}$ & $\begin{array}{l}\text { Barely had no } \\
\text { improvement. }\end{array}$ & $\begin{array}{l}\text { Students evaluate } \\
\text { themselves, but } \\
\text { still lack of } \\
\text { teacher's } \\
\text { evaluation in the } \\
\text { process. }\end{array}$ & \\
\hline \multirow[b]{2}{*}{ Third } & 20 & 15 & 20 & 20 & 20 & \multirow[b]{2}{*}{$\begin{array}{c}\text { Agreed, } \\
\text { understanding the } \\
\text { 5E instructional } \\
\text { model entirely. }\end{array}$} \\
\hline & $\begin{array}{l}\text { Caused students' } \\
\text { cognitive conflict and } \\
\text { elicited students' } \\
\text { prior knowledge. }\end{array}$ & $\begin{array}{l}\text { The exploration } \\
\text { improved, but still } \\
\text { lack of probing } \\
\text { questions. }\end{array}$ & $\begin{array}{l}\text { Students } \\
\text { constructed new } \\
\text { knowledge and } \\
\text { teacher gave them } \\
\text { supplement. }\end{array}$ & $\begin{array}{c}\text { Extending } \\
\text { students' } \\
\text { conceptual } \\
\text { understanding and } \\
\text { skills through new } \\
\text { experience. }\end{array}$ & $\begin{array}{l}\text { Students evaluated } \\
\text { themselves and } \\
\text { teacher valuated } \\
\text { students in } \\
\text { progress. }\end{array}$ & \\
\hline
\end{tabular}

Table 10. XBB's specific situation of instructional design across the three stages

\begin{tabular}{|c|c|c|c|c|c|c|}
\hline \multirow{2}{*}{ Stage } & \multicolumn{5}{|c|}{ Teaching process design $(20 * 5)$} & \multirow{2}{*}{$\begin{array}{c}\text { Identification of } \\
\text { the } 5 \mathrm{E}\end{array}$} \\
\hline & Engagement & Exploration & Explanation & Elaboration & Evaluation & \\
\hline \multirow[b]{2}{*}{ First } & 15 & 15 & 15 & 10 & 15 & \multirow[b]{2}{*}{$\begin{array}{c}\text { Agreed, viewing } \\
5 \mathrm{E} \text { instructional } \\
\text { model as a } \\
\text { direction. }\end{array}$} \\
\hline & $\begin{array}{l}\text { Caused students' } \\
\text { cognitive conflict, } \\
\text { and elicited students' } \\
\text { prior knowledge }\end{array}$ & $\begin{array}{l}\text { Provided students } \\
\text { with a common } \\
\text { base of activities, } \\
\text { but still lack of } \\
\text { probing questions. }\end{array}$ & $\begin{array}{c}\text { students } \\
\text { constructed new } \\
\text { knowledge with a } \\
\text { little teacher's } \\
\text { supplement. }\end{array}$ & $\begin{array}{l}\text { The new } \\
\text { knowledge was to } \\
\text { applied in familiar } \\
\text { question situation. }\end{array}$ & $\begin{array}{l}\text { Students evaluate } \\
\text { themselves, but } \\
\text { lack of teacher's } \\
\text { evaluation. }\end{array}$ & \\
\hline \multirow[b]{2}{*}{ Second } & 15 & 18 & 15 & 15 & 15 & \multirow[b]{2}{*}{$\begin{array}{l}\text { Agreed, guided } \\
\text { by } 5 \mathrm{E} \\
\text { instructional } \\
\text { model. }\end{array}$} \\
\hline & $\begin{array}{l}\text { Improved, but failed } \\
\text { to come up with a } \\
\text { problem. }\end{array}$ & $\begin{array}{l}\text { Realized the } \\
\text { students } \\
\text { exploration with } \\
\text { probing questions. }\end{array}$ & $\begin{array}{c}\text { Teacher } \\
\text { explanation mostly } \\
\text { with students } \\
\text { construction. }\end{array}$ & $\begin{array}{l}\text { Applied the new } \\
\text { knowledge in stage } \\
\text { experiences. }\end{array}$ & $\begin{array}{l}\text { Students evaluate } \\
\text { themselves, but } \\
\text { still lack of } \\
\text { teacher's } \\
\text { evaluation in the } \\
\text { process. }\end{array}$ & \\
\hline \multirow[b]{2}{*}{ Third } & 20 & 18 & 20 & 15 & 18 & \multirow[b]{2}{*}{$\begin{array}{l}\text { Agreed the 5E } \\
\text { instructional } \\
\text { model entirely. }\end{array}$} \\
\hline & $\begin{array}{l}\text { Caused students' } \\
\text { cognitive conflict and } \\
\text { came up with } \\
\text { problem to explored. }\end{array}$ & $\begin{array}{l}\text { Improved, and the } \\
\text { exploration was } \\
\text { designed prefect. }\end{array}$ & $\begin{array}{c}\text { Students } \\
\text { constructed new } \\
\text { knowledge and } \\
\text { teacher gave them } \\
\text { supplement. }\end{array}$ & $\begin{array}{l}\text { Barely had no } \\
\quad \text { further } \\
\text { improvement. }\end{array}$ & $\begin{array}{l}\text { Improved, teacher } \\
\text { valuated students } \\
\text { in progress better. }\end{array}$ & \\
\hline
\end{tabular}

ZRL showed improvement in the instructional design process across all three periods of engagement. In the first period, ZRL aimed for designing the problem scenario to trigger the students' attention, while also designing problems to explore the students' original cognitions. In the second period, ZRL was able to trigger the students' conflict cognitions, then in the third period, ZRL was able to design problems for instructing the students to explore the problems naturally. In the third period, however, ZRL's design activities showed significant improvement, which stimulated the students' ability to take the initiative in class activities. As for the explanation phase, the improvement in the instructional design process was not stable across the three periods. In the elaboration phase, ZRL identified with the model extremely well in the first period, in which an awareness of the students' self-evaluations is important. ZRL was able to incorporate her students' self-evaluations into her instructional design process; however, her student evaluations were still lacking in quality. The same problems also appeared in the following two periods, that is, no new development or improvement was observed. 
Table 11. ZRL's specific situation of instructional design across the three stages

\begin{tabular}{|c|c|c|c|c|c|c|}
\hline \multirow{2}{*}{ Stage } & \multicolumn{5}{|c|}{ Teaching process design $(20 * 5)$} & \multirow{2}{*}{$\begin{array}{l}\text { Identification of } \\
\text { the } 5 \mathrm{E}\end{array}$} \\
\hline & Engagement & Exploration & Explanation & Elaboration & Evaluation & \\
\hline \multirow[b]{2}{*}{ First } & 10 & 10 & 13 & 10 & 15 & \multirow{2}{*}{$\begin{array}{l}\text { Agreed basically, } \\
\text { but the } \\
\text { understanding } \\
\text { needs to be } \\
\text { improved. }\end{array}$} \\
\hline & $\begin{array}{l}\text { Created a question } \\
\text { situation but only } \\
\text { raised students' } \\
\text { attention. }\end{array}$ & $\begin{array}{l}\text { Most of the } \\
\text { exploration was } \\
\text { done by teacher. }\end{array}$ & $\begin{array}{c}\text { Teacher } \\
\text { explanation mostly } \\
\text { with students' } \\
\text { construction. }\end{array}$ & $\begin{array}{l}\text { The new } \\
\text { knowledge was to } \\
\text { applied in the } \\
\text { common exercise. }\end{array}$ & $\begin{array}{c}\text { Students evaluate } \\
\text { themselves, but } \\
\text { lack of teacher's } \\
\text { evaluation. }\end{array}$ & \\
\hline \multirow[b]{2}{*}{ Second } & 15 & 10 & 15 & 15 & 15 & \multirow[b]{2}{*}{$\begin{array}{l}\text { Agreed, but } \\
\text { worried when } \\
\text { used it. }\end{array}$} \\
\hline & $\begin{array}{l}\text { Caused students' } \\
\text { cognitive conflict, } \\
\text { but lack of eliciting } \\
\text { students' prior } \\
\text { knowledge. }\end{array}$ & $\begin{array}{l}\text { Barely had any } \\
\text { improvement. }\end{array}$ & $\begin{array}{c}\text { Students } \\
\text { constructed new } \\
\text { knowledge and } \\
\text { teacher gave them } \\
\text { supplement. }\end{array}$ & $\begin{array}{l}\text { The new } \\
\text { knowledge was to } \\
\text { applied in the } \\
\text { interesting } \\
\text { situation. }\end{array}$ & $\begin{array}{l}\text { Barely had any } \\
\text { improvement. }\end{array}$ & \\
\hline \multirow[b]{2}{*}{ Third } & 18 & 15 & 10 & 15 & 15 & \multirow[b]{2}{*}{$\begin{array}{l}\text { Agreed, but most } \\
\text { of the activities } \\
\text { were still done by } \\
\text { teachers. }\end{array}$} \\
\hline & $\begin{array}{l}\text { Improved, began to } \\
\text { come up with } \\
\text { problem to explored. }\end{array}$ & $\begin{array}{l}\text { Providing students } \\
\text { with a common } \\
\text { base of activities, } \\
\text { but didn't carry out } \\
\text { probing questions. }\end{array}$ & $\begin{array}{l}\text { Most of the new } \\
\text { knowledge was } \\
\text { told by teacher. }\end{array}$ & $\begin{array}{c}\text { Extending } \\
\text { students' } \\
\text { conceptual } \\
\text { understanding and } \\
\text { skills in different } \\
\text { angles. }\end{array}$ & $\begin{array}{l}\text { Students evaluate } \\
\text { themselves, but } \\
\text { still lack of } \\
\text { teacher's } \\
\text { evaluation in the } \\
\text { process. }\end{array}$ & \\
\hline
\end{tabular}

\subsubsection{Similarities and Differences between the Different} Novice Teachers in the Development of Their Instructional Design Processes

Based on the similarities observed across all three periods, the novice teachers all seemed to experience, become familiar with, and understand the application and design of the model in a similar manner. Following the three periods of instruction and practical design, the analysis results showed that the model produced positive influences in the instructional design processes of the novice teachers. The novice teachers were able to not only reconsider the design of their original (pre-guidance) teaching processes based on the information they received on the model, but they were also able to identify weak points in their original teaching processes and modify them effectively. The variations among the three novice teachers' instructional design processes for each period in the different phases are shown in Figure 3.

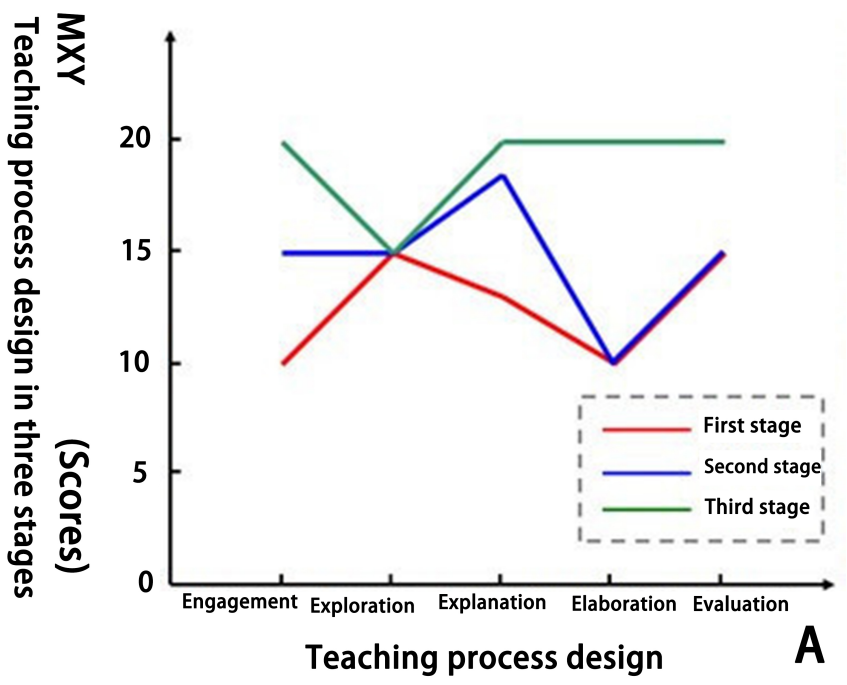

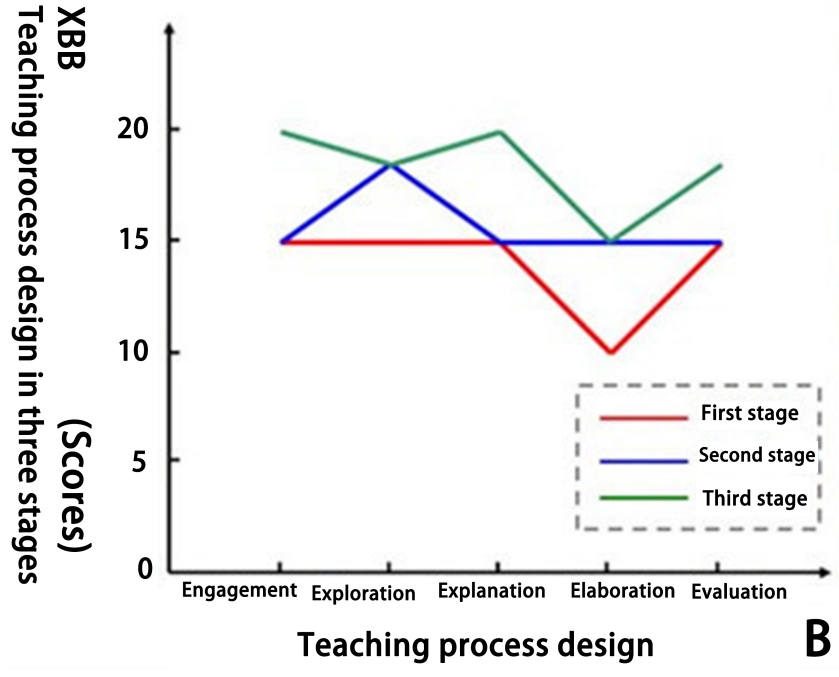

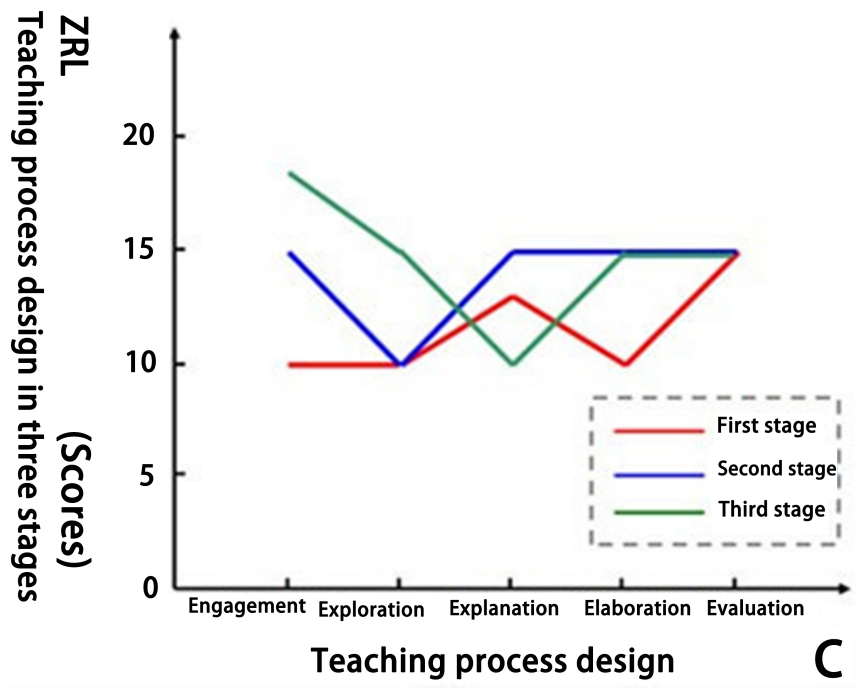

Figure 3. Instructional design process improvements of the three novice teachers across the different stages 
According to the analysis shown in Figure 3, MXY achieved the best overall improvement based on the differences in the points of development and improvement across the entirety of the instructional design process. She reached the target at every phase in this study except for the exploration phase. The reason for this significant improvement for MXY in instructional design was that she developed a good understanding of and was able to clearly identify the model; moreover, she was able to learn more about education theories in her postgraduate study. In addition, MXY was found to do much better in her instructional design through further instructing practice and applying theories of education. In her opinion, "the $5 \mathrm{E}$ instructional model will guide novice teachers effectively in developing their processes of instructional design, because it lists required criteria clearly at every period and phase." For MXY, the greatest benefit of the model was the evaluation aspect, and in particular the aspect of process evaluation. Meanwhile, the stimulation of student conflict cognitions in the engagement phase was also very useful for her. Conversely, ZRL noted that she sometimes worried about the effects of the model in her instructional design process, which caused her to often revert back to her original (pre-guidance) teaching process. Therefore, ZRL showed relatively little change on the whole with respect to her instructional design process; moreover, her instructional design process appeared somewhat unstable. In sum, the above results demonstrate that one's degree of confidence and ability to identify the model can affect the improvement of the instructional design processes of novice teachers.

Even though MXY achieved the best overall improvement in instructional design, she nonetheless showed no improvement in the exploration phase, as shown in Figure 3, while XBB showed the best improvement in the exploration phrase. The likely reason for this difference is that XBB did more research and reflection with respect to the practical processes involved in teaching. Therefore, XBB communicated with the researcher at every phase and period of instruction, and reflected much on the experiences, resulting in his being able to perform the best in the exploration phase, and also better apply the model to the students' self-exploration activities. In his opinion, "The exploration is not just limited to the original operation of the experiment after the study of the $5 \mathrm{E}$ instructional model, because the reference materials are also prime content for exploration. In the original (pre-guidance) exploration stages, the main objective was to obtain the conclusion through experimentation, while the exploration phase in the $5 \mathrm{E}$ instructional model not only allows the students to obtain the conclusion by themselves, but it also instructs the students to construct and resolve the cognition aspects themselves according to the problems. The students' cognitions may be simple, or one-sided, understandings, and they may not even be correct, but it is the process itself that provides the real evidence for students attempting to resolve their cognition conflicts." In this way, XBB was able to gain additional insights through reflection on the teaching process based on the model, resulting in an improved exploration phase.

We can thus see that even though the three abovementioned case studies were conducted under the same instruction and training, the specific cognitions and behaviors with respect to each individual's instructional design process were different. According to the results of our study, including the interviews we conducted with the three novice teachers, the main differences observed between the teachers derived from differences in educational background, confidence in one's ability to teach, a sense of identity as a teacher, habits of reflecting on one's teaching experiences, one's actual teaching experience, and the conditions of the students being taught.

\section{Conclusions}

The analyses of the collected data for the novice teachers on their instructional design processes based on the $5 \mathrm{E}$ model demonstrated that the model can produce a positive impact on the development and improvement of novice teachers in their efforts at instructional design. In our study, the novice teachers improved their instructional design processes after being trained in the model. The reason for the observed improvement was that the model provided a good template for the novice teachers, and that they were therefore able to constantly and consistently further develop their ability to teach by refining their instructional design process. In addition, we also found that the observed improvement among the novice teachers was stable across time. Their abilities to design instructional processes all improved, and in particular the three novice teachers chosen for the case studies showed increased familiarity, identification, understanding, application, and self-design of the various aspects of the model. However, we also found that the specific improvements were different for each novice teacher. Therefore, though the model on the whole had positive effects on the novice teachers with respect to their instructional design processes, their specific improvements were also affected by the teachers' confidence in teaching, understanding of the relevant theories, ability to self-reflect on their teaching ability, and the conditions of their students.

The most important conclusion of this study is the fact that the model influenced and improved the ways in which the novice chemistry teachers were able to design their own teaching processes. In this sense, we can say that the research objective was achieved. In addition, the further refinement and improvement of the model itself is also a worthwhile further study objective. All such research will be of potential value for the further development and improvement of teachers with respect to the design of instructional processes based on the $5 \mathrm{E}$ instructional model.

\section{Acknowledgements}

We are very grateful to the Faculty of Education of 
Beijing Normal University for financing this study.

\section{REFERENCES}

[1] Bybee R W, Taylor J A, Gardner A, et al. The BSCS 5E instructional model: Origins and effectiveness, Colorado Springs, CO: BSCS, 2006.

[2] Lawson AE. Using the Learning Circle to Teach Biology Concepts and Reasoning Patterns, Journal of Biological Science Education, Vol.35, No.4, 165-169, 2001

[3] Bybee R W. The BSCS 5E instructional model and 21st century skills. National Academies Board on Science Education, Washington, DC: Retrieved March, 2009, 4: 2011.

[4] Çepni S, Şahin Ç, Ipek H. Teaching floating and sinking concepts with different methods and techniques based on the 5E instructional model. //Asia-Pacific Forum on Science Learning and Teaching. Hong Kong Institute of Education. 10 Lo Ping Road, Tai Po, New Territories, Hong Kong, Vol.11, No.2, 1-39, 2010.

[5] Liu T C, Peng $\mathrm{H}, \mathrm{Wu} \mathrm{W} \mathrm{H}$, et al. The Effects of Mobile Natural-science Learning Based on the 5E Learning Cycle: A Case Study, Educational Technology \& Society, Vol.12, No.4, 344-358, 2009.
[6] Çepni S, Sahin Ç. Effect of different teaching methods and techniques embedded in the $5 \mathrm{E}$ instructional model on students' learning about buoyancy force, Eurasian Journal of Physics and Chemistry Education, Vol. 4, No.2, 2012.

[7] Artun H, Coştu B. Effect of the 5E model on prospective teachers' conceptual understanding of diffusion and osmosis: A mixed method approach, Journal of Science Education and Technology, Vol.22, No.1, 1-10, 2013.

[8] Tural G, Akdeniz A R, Alev N. Effect of 5E teaching model on student teachers' understanding of weightlessness, Journal of Science Education and Technology, Vol.19, No.5, 470-488, 2010 .

[9] Kedzior M, Fifield S. Teacher professional development, Education Policy Brief, Vol.15, No.21, 76-97, 2004

[10] Avalos B. Teacher professional development in Teaching and Teacher Education over ten years, Teaching and teacher education, Vol. 27, No.1, 10-20,2011.

[11] Schlager M S, Fusco J. Teacher professional development, technology, and communities of practice: Are we putting the cart before the horse? The Information Society, Vol.19, No.3, 203-220, 2003.

[12] Borko H. Professional development and teacher learning: Mapping the terrain, Educational researcher, Vol.33, No.8, 3-15, 2004. 